\title{
GROWTH AND MORTALITY OF THE KING ANGELFISH, HOLACANTHUS PASSER (ACTINOPTERYGII: PERCIFORMES: POMACANTHIDAE), IN THE CENTRAL GULF OF CALIFORNIA, MEXICO
}

\author{
Francisco J. FERNÁNDEZ-RIVERA MELO ${ }^{1,2^{*}}$, Héctor REYES-BONILLA², \\ Jorge A. LÓPEZ-ROCHA ${ }^{3}$, and Carlos A. SALOMON-AGUILAR ${ }^{2}$ \\ ${ }^{1}$ Comunidad y Biodiversidad A.C., Guaymas Sonora, México \\ ${ }^{2}$ Departamento Académico de Ciencias Marinas y Costeras, Universidad Autónoma de Baja California Sur, La Paz, \\ B.C.S., México \\ ${ }^{3}$ Unidad Multidisciplinaria de Docencia e Investigación, Facultad de Ciencias, Universidad Nacional Autónoma de \\ México, Sisal, Yucatán, México
}

\begin{abstract}
Fernández-Rivera Melo F.J., Reyes-Bonilla H., López-Rocha J.A., Salomon-Aguilar C.A. 2016. Growth and mortality of the king angelfish, Holacanthus passer (Actinopterygii: Perciformes: Pomacanthidae), in the central Gulf of California, Mexico. Acta Ichthyol. Piscat. 46 (4): 293-301.
\end{abstract}

\begin{abstract}
Background. The king angelfish, Holacanthus passer Valenciennes, 1846, is one of the principal species captured in the Gulf of California, Mexico, for the purpose of the aquarium trade. Although the species has been exploited for more than 40 years, studies have not yet been undertaken to understand the population parameters required for adequate management of the fishery. The objective of this work was to describe for the first time the growth and mortality of this species. The information provided in this study contributes to the generation of knowledge necessary to establish sustainable management practices.

Materials and methods. The growth curve of the species was determined by applying a modal progression analysis of the sample length frequency distribution to determine the number of cohorts present through the multinomial statistic based on a probability function. Once the cohorts were identified, the von Bertalanffy growth model was adjusted using a maximum likelihood function. To estimate the natural mortality rate and natural mortality-at-age, empirical methods were used. Were also estimated the size and age at first maturity $\left(L_{\mathrm{m}}, t_{\mathrm{m}}\right)$, the maximum age $\left(t_{\max }\right)$, the fishing mortality $(F)$, the total mortality $(Z)$, and the exploitation rate $(E)$.

Results. In total, 794 king angelfish were measured and weighed, including 659 juveniles and 135 adults. The total length of the fish ranged from 3 to $29 \mathrm{~cm}$, and the weight was within 2-797 g. The potential weight-length relation was significant $\left(r^{2}=0.94 ; P>0.01\right)$, showing a negative allometric curve with the parameters: $a=0.108$ and $b=2.618$. The parameters of the von Bertalanffy growth equation were: $L_{\infty}=37.894 \mathrm{~cm}, k=0.127$ year $^{-1}, t_{0}$ $=-0.658$ years. The natural mortality rate was estimated to be 0.315 year $^{-1}$. The following values were estimated for: $L_{\mathrm{m}}=21.835 \mathrm{~cm}, t_{\mathrm{m}}=6.10$ years, $t_{\max }=20.01$ years, $Z=1.19$ year $^{-1}, F=0.88$ year $^{-1}$, and $E=0.74$.
\end{abstract}

Conclusion. Estimates of natural mortality could be linked to management measures such as catch quotas.

Keywords: von Bertalanffy, natural mortality, fisheries management, weight-length, aquarium fish

\section{INTRODUCTION}

Ornamental fisheries are becoming an important option to sustain the economies of coastal communities in developing countries (Wabnitz et al. 2003). It is estimated that in Mexico there are more than 200 species targeted by the commercial fisheries for aquarium purposes. Those species constitute $36 \%$ of the reef fish species of the Gulf of California and the Mexican Pacific (Piña-Espallargas et al. 2000). Buyers are especially interested in colourful species such as angelfish, belonging to the family Pomacanthidae. This family includes 88 species in nine genera (Eschmeyer and Fricke 2015) that are found in every tropical ocean: eight in the Atlantic, 77 in the Indo-Pacific, and three in the Eastern Tropical Pacific. All Pacific species represent the genus Holacanthus: Holacanthus clarionensis Gilbert, 1890; Holacanthus limbaughi Baldwin, 1963; and king angelfish, Holacanthus passer Valenciennes, 1846, (see Robertson and Allen 2015). 
The king angelfish, Holacanthus passer (thereafter angelfish), inhabits the intertidal zone and depths down to $80 \mathrm{~m}$, although it is most commonly found between 0 and $30 \mathrm{~m}$ of depth (Thompson et al. 2000) with a distribution ranging from Cabo Tepoca and Bahía de Los Ángeles in the northern Gulf of California $\left(29^{\circ} \mathrm{N}\right)$, to the coasts of Peru $\left(5^{\circ} \mathrm{S}\right)$, including the oceanic islands, Revillagigedo, Galápagos, Malpelo, and Cocos (Robertson and Allen 2015). This pomacanthid fish can grow up to $36 \mathrm{~cm}$ in total length, it is predominantly found in rocky and coralline reefs, or in specialized habitats such as black coral gardens (Robertson and Allen 2015). This species is of great economic importance as there is already a broad market for it in the aquarium trade; one fish can sell for up to USD 200 near the beach (Sánchez-Alcántara et al. 2006) as a result of its notable beauty in the juvenile phase. The ornamental value of the species has motivated its capture since the 1970s, especially in rocky reefs within the Gulf of California (Reyes-Bonilla et al. 2009), but with minimal precaution and without reliable biological information. Due to the possibility that the unmanaged exploitation of juveniles could affect populations, the king angelfish was declared a "species under special protection" by the Mexican government (Anonymous 2010). The category is imposed on those species or populations that might be threatened by factors that affects its long-term viability, and therefore are in need for conservation. Under this scenario, there are restrictions on the utilization of the king angelfish, as well as regulations on its capture (Anonymous 2012). Among them is a fishery conducted under sustainability criteria including annual monitoring of the populations and analyses of sizes, and from that information follows the calculation of exploitation rates and fishing gear, all conducted inside specific polygons awarded to groups of organized fishermen. Currently, the king angelfish is not listed by the Conservation of International of Trade in Endangered Species of Wild Fauna and Flora (CITES), and is considered in the category of Least Concern by the Red List of the International Union for Conservation of Nature (UICN) (Pyle et al. 2010).

Regarding Holacanthus passer in the Eastern Pacific, the only data available are related to the abundance (PérezEspaña et al. 1996, Villáreal-Cavazos et al. 2000, AburtoOropeza and Balart 2001, Arreola and Elorduy-Garay 2002, Alvarez-Filip et al. 2006, Viesca et al. 2008), reproduction (Arellano-Martínez et al. 1999), and trophic ecology (Aburto et al. 2000). To this day information does not exist regarding individual growth patterns or mortality. Consequently, in order to contribute to the existing knowledge base and improve the marine resource management of ornamental fisheries, the objective of this project was to estimate the parameters of the von Bertalanffy growth equation for $H$. passer, as well as its natural mortality rate, making it the first study of this type for a pomacanthid species in the Eastern Pacific. To perform the study we relied only on analyses of sizes because as $H$. passer is under protection by federal law in Mexico and the specimens are sold alive, the use of hard structures such as otoliths cannot be considered.

\section{MATERIALS AND METHODS}

Study area. The research study was carried out within Bahia de Loreto National Park (PNBL), located between the coordinates $25^{\circ} 35^{\prime} 18.41^{\prime \prime}$ and $26^{\circ} 07^{\prime} 48.72^{\prime \prime} \mathrm{N} ; 110^{\circ} 45^{\prime} 00^{\prime \prime}$ and $111^{\circ} 21^{\prime} 08.67^{\prime \prime} \mathrm{W}$, in the Eastern-central portion of the state of Baja California Sur (Fig. 1). The PNBL is one of the largest protected water bodies in the Gulf of California. Three sampling sites were established in the southern portion of the park: El Submarino, Galeras, and Luna de Miel. In the study region the mean annual surface temperature was $22.6^{\circ} \mathrm{C}$ (Locarnini et al. 2010).

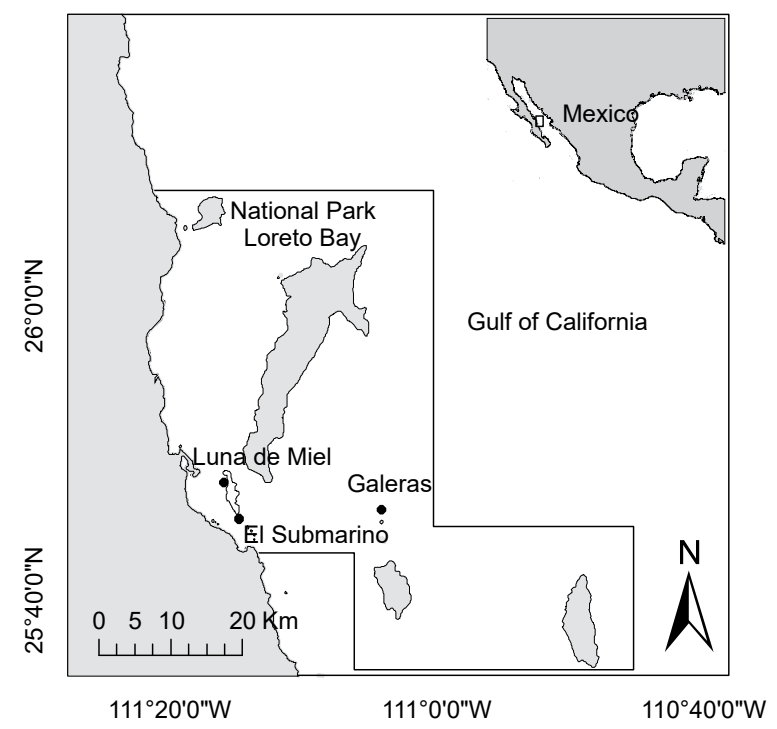

Fig. 1. Study area in Bahía de Loreto National Park, central Gulf of California

Field work. During the month of May 2009, individuals of the angelfish were collected using hand nets (juveniles) or seine nets measuring $6 \mathrm{~m}$ in length by $1 \mathrm{~m}$ in height with $0.5 \mathrm{~cm}$ mesh (adults). Following the capture, the total length (TL) of each organism was measured with a fish ruler of $\pm 1 \mathrm{~mm}$ precision, and weighed using a digital scale with $\pm 0.01 \mathrm{~g}$ precision.

Weight-length relation. The relation between the weight and total length data were calculated by way of a power regression model (Haddon 2001):

$$
y=a x^{b}
$$

of which the constants were determined with nonlinear least squares (Sokal and Rohlf 1975) using the GaussNewton algorithm. The hypothesis of isometric growth (Ricker 1975) was tested using a Student's $t$-test (Zar 2010).

Modal progression analysis. The length frequency distribution was analysed using the process described by Velázquez-Abunader et al. (2016). The length frequency histogram was created with class size intervals of $1 \mathrm{~cm}$, as the maximum recorded length during this study did not exceed $30 \mathrm{~cm}$. 
The modal groups observed in the length frequency distribution were adjusted to the multinomial model described as follows:

$$
P\left\{x_{i} \mid n, p_{1}, p_{2}, \ldots, p_{k}\right\}=n ! \prod_{i=1}^{k} \frac{p_{i}^{x_{i}}}{x_{i} !}
$$

where $x_{i}$ is the number of times an event of type $i$ occurs in $n$ samples, $n$ is the sample size and $p_{i}$ are the separate probabilities of each of $k$ possible events (Haddon 2001). To estimate the parameters of the model the above equation was transformed into a probability expression, resulting in the following equation:

$$
-\ln L\left\{x_{i} \mid n, p_{1}, p_{2}, \ldots, p_{k}\right\}=\sum_{i=1}^{n}\left[x_{i} \ln \left(p_{i}\right)\right]
$$

In order to estimate the model parameters, the assumption must be met that the size distribution of each modal group is normally distributed, and that each mode present in the length frequency distribution represents one cohort of the population (Haddon 2001). Under this condition, estimations of expected relative proportions of each length interval were described using the following density function:

$$
P_{L}=\frac{1}{\sigma_{n} \sqrt{2 \pi}} \mathrm{e}^{\frac{-\left(L-\mu_{n}\right)^{2}}{2 \sigma^{2}}}
$$

where $\mu_{n}$ and $\sigma_{n}$ are the mean and standard deviation of length for each modal group. The expected frequencies were estimated using the logarithmic function of the multinomial distribution and the final values of the model parameters were determined through the comparison of observed and expected frequencies (Haddon 2001). The objective function for parameter estimation was defined as follows:

$$
-\ln L\left\{L \mid \mu_{i}, \sigma_{i}\right\}=-\sum_{i=1}^{n} L_{i} \ln \left(\hat{p}_{i}\right)=-\sum_{i=1}^{k} L_{i} \ln \left(\frac{\hat{L}_{i}}{\sum \hat{L}_{i}}\right)
$$

The seed values for the estimation of the parameters (number of modes, mean length of each mode and its standard deviation) were obtained using the Bhattacharya (1967) method in the FiSAT II program (Gayanilo et al. 2005). The parameters of the model were estimated when the negative log likelihood function was minimized, for which Newton's adjusted nonlinear algorithm was used (Neter et al. 1996).

To determine the effective separation of modal groups, the Separation Index (SI) proposed by Sparre and Venema (1997) was utilized:

$$
\mathrm{SI}=\frac{L_{j}-L_{i}}{\left(\frac{S_{j}^{2}+S_{i}^{2}}{2}\right)} \geq 2
$$

where $L_{j}$ and $L_{i}$ are the mean lengths of the modal $j$ and $i$, $S^{2}{ }_{j}$ and $S^{2}{ }_{i}$ are the standard deviations of the modal groups $j$ and $i$. When SI $<2$ it was not feasible to separate the normal components of the observed frequencies (Sparre and Venema 1997).

To apply the model an age of 0.5 years was assigned to the cohort with the smallest mean total length; this choice was taken because the season of highest reproductive intensity of Holacanthus passer occurs in November (Arellano-Martínez et al. 1999), accordingly, the individuals pertaining to the cohort with the smallest mean length in the month of May when the study was carried out, would be aged approximately six months $t_{1}$ $=0.5$ years. After the first cohort, the following cohorts were annual $(t+1)$, except in the cases where growth rate $\left(L_{j}-L_{i}\right) \cdot\left(t_{j}-t_{i}\right)^{-1}$, a product of the increasing mean length between successive cohorts, did not fit the assumption of the von Bertalanffy model, stating that the growth rate decreases as age increases. In those particular cases, the age assigned to the specific cohort was increased by one year, assuming an intermediate cohort that was not identifiable due to the overlap of modal groups (Sparre and Venema 1997).

von Bertalanffy growth equation. The von Bertalanffy growth model (von Bertalanffy 1938) was fitted to the data for mean length of each identified cohort, defined by the equation:

$$
L_{t}=L_{\infty}\left[1-e^{-k\left(t-t_{0}\right)}\right]
$$

where $L_{t}$ is the mean total length for age $t, L_{\infty}$ is the asymptotic length, $k$ is growth coefficient, $t$ is age in years, and $t_{0}$ is hypothetical age when $L_{t}=0$.

Since in this study large sizes were poorly represented, the asymptotic length was estimated as $L_{\infty}=L_{\max } \cdot 0.95^{-1}$ (Pauly 1984). Where $L_{\max }$ is the maximum reported length of the species, $L_{\text {max }}=36 \mathrm{~cm}$ (Robertson and Allen 2015). The remaining model parameters, $k$ and $t$, were estimated by minimizing the negative value of the log-likelihood (Hilborn and Manguel 1997) through Newton's algorithm:

$$
-\ln L(\theta \mid \text { data })=\sum_{t}\left[-\frac{1}{2} \ln (2 \pi)\right]-\left[\frac{1}{2} \ln \left(\sigma^{2}\right)-\left(\frac{\ln L_{t}-\ln \hat{L}_{t}^{2}}{2 \sigma^{2}}\right)\right]
$$

where $(\theta)$ represents the parameters of the model.

The value of the standard deviation was obtained using:

$$
\sigma=\sqrt{\frac{1}{n} \sum_{t=1}^{n}\left(\ln L_{t}-\ln L_{t}\right)^{2}}
$$

where $n$ is the number of observations (Hilborn and Walters 1992). The confidence intervals (95\%) were estimated for $k$ and $t_{0}$ using the likelihood profiles of each parameter (Haddon 2001).

The increase in weight was described by transforming $L_{\infty}$ to asymptotic weight through the length-weight 
relation calculated in this study (Sparre and Venema 1997) and using the formula:

$$
W_{t}=W_{\infty}\left[1-e^{-k\left(t-t_{0}\right)}\right]^{b}
$$

where: $W_{\infty}$ is the mean asymptotic weight, and $b$ is the power of the length-weight relation curve.

Once the VBGE were estimated, the next step was to calculate the maturity length $\left(L_{\mathrm{m}}\right)$ and age $\left(t_{\mathrm{m}}\right)$, as well as the longevity $\left(t_{\max }\right)$ using the empirical equations proposed by Froese and Binohlan (2000).

Mortality This parameter is among the most difficult to estimate in a natural population (Vetter 1988), and in this paper we applied the method of Hoenig (1983), based on the expected maximum age of the individuals, $t_{\max }$ (Then et al. 2015). This procedure relates the maximum age with natural mortality according to the equation:

$$
M=4.899 t_{\max }^{-0.916}
$$

In addition, a second estimation of natural mortality was obtained due to the fact that as the fishery comprises both juveniles and adults, and the former support an important part of the effort and catch. The evaluation of mortality depending on age was done with the method of Chen and Watanabe (1989). As mortality $(M)$ and growth $(k)$ of a species are inversely linked, $M$ is dependent of the age of sexual maturity and follows the relation:

$$
\begin{gathered}
M(t)=\frac{\mathrm{k}}{\left(1-e^{-\mathrm{k}\left(\mathrm{t}-\mathrm{t}_{\mathrm{o}}\right)}\right)} \text { to } t<t_{\mathrm{m}} \\
M(t)=\frac{k}{a_{0}}+a_{1}\left(t-t_{\mathrm{m}}\right)+a_{2}\left(t-t_{\mathrm{m}}\right)^{2} \text { to } t>t_{\mathrm{m}}
\end{gathered}
$$

where: $a_{0}=1-e^{-k\left(t_{\mathrm{m}}-t_{0}\right)} ; \quad a_{1}=k e^{-k\left(t_{\mathrm{m}}-t_{0}\right)} ; \quad$ and $a_{2}=-0.5 k^{2 e^{\left(-k\left(t_{\mathrm{m}}-t_{0}\right)\right)}}$.

Total mortality $(Z)$ was then estimated from the sizeconverted catch curve (Pauly and Ingles 1981), and once with a value of $Z$ and $M$ (this one, according to the method of maximum age $t_{\max }$; Then et al. 2015), the fishing mortality was calculated as

$$
F=Z-M
$$

and the exploitation rate $(E)$ as

$$
E=F \cdot Z^{-1}
$$

\section{RESULTS}

A total of 794 individuals of king angelfish were captured at the National Park Loreto Bay, with total lengths ranging from 3 to $29 \mathrm{~cm}$ and weights varying between 2 and $767 \mathrm{~g}$. Considering a minimum adult size of $13 \mathrm{~cm}$ in length, there were 659 juveniles and 135 adults (Fig. 2).
The juveniles were easily identified as they exhibited an orange coloration of the anterior body, 5-6 narrow lateral blue bars, blue borders of the dorsal and anal fins, and an orange caudal fin.

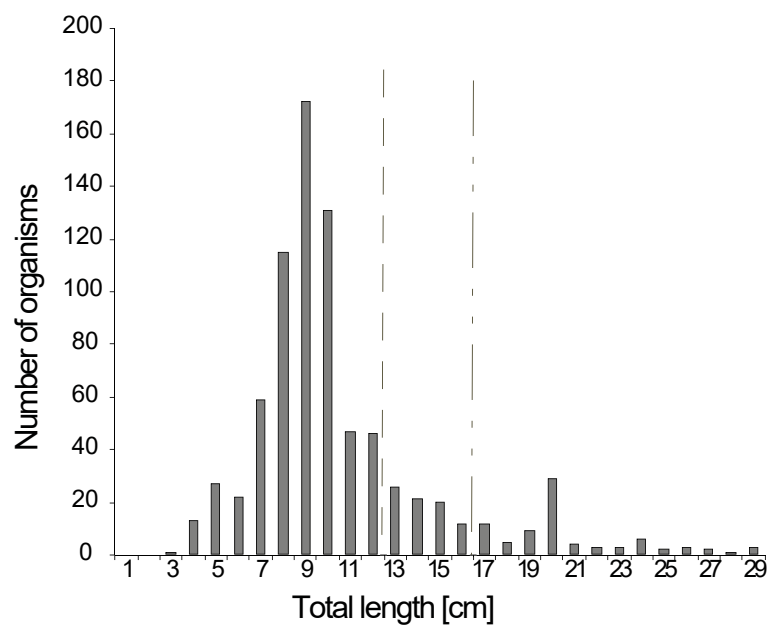

Fig. 2. Histogram of length structure of king angelfish, Holacanthus passer; Dashed line on left separates juvenile from adult fish, according to colorations observed in the field, whereas the double spotted line on the right indicates the length at first maturity

The weight-length relation (Fig. 3) was significant $\left(r^{2}\right.$ $=0.94 ; P>0.01)$, the intercept was estimated as $0.108 \pm$ 0.009 and the exponent as $2.62 \pm 0.03$. It was determined that the king angelfish represents a negative allometric relation between length and weight, given that the value of the slope or growth coefficient $(b=2.62)$ was significantly different than 3 (Student's $t=-12.95, P<0.05$ ).



Fig. 3. Length-weight relation of king angelfish, Holacanthus passer in the Gulf of California

Growth model. Six modal groups were identified in the length frequency distribution using the method of Bhattacharya (1967). The mean lengths and standard deviations of each modal group were used as seed values to estimate the modal groups using the maximum likelihood method (Table 1). Four modal groups were clearly identified (Fig. 4), although it was not possible to define the fourth modal group with a mean total length of $14.39 \mathrm{~cm}$, and the sixth modal group with a mean total length of $24.39 \mathrm{~cm}$, as cohorts due to the separation indices lower than two $(\mathrm{SI}<2)($ Table 1$)$. 
Table 1 total length of $4.95 \mathrm{~cm}$. The following cohorts were annual

Length values for each modal group (cohort) distinguished in the length-frequency distribution of king angelfish, Holacanthus passer, in the Gulf of California, Mexico

\begin{tabular}{|c|c|c|c|c|c|c|c|}
\hline \multirow[b]{2}{*}{ Cohort } & \multicolumn{3}{|c|}{$\begin{array}{l}\text { Length }[\mathrm{cm}] \\
\text { (seed values) }\end{array}$} & \multicolumn{4}{|c|}{$\begin{array}{c}\text { Length }[\mathrm{cm}] \text { (estimated } \\
\text { values) }\end{array}$} \\
\hline & Mean & $\mathrm{SD}$ & Factor & Mean & $\mathrm{SD}$ & Factor & SI \\
\hline 1 & 5.24 & 0.85 & 50 & 4.95 & 0.78 & 50.76 & $\mathrm{n} / \mathrm{a}$ \\
\hline 2 & 8.93 & 1.30 & 550 & 8.96 & 1.28 & 540.19 & 3.57 \\
\hline 3 & 11.36 & 0.70 & 70 & 12.34 & 0.38 & 37.56 & 3.80 \\
\hline 4 & 16.50 & 1.07 & 50 & 14.39 & 1.99 & 98.62 & $0.99 *$ \\
\hline 5 & 19.89 & 0.55 & 50 & 19.82 & 0.46 & 32.33 & 2.60 \\
\hline 6 & 23.89 & 0.75 & 25 & 24.39 & 5.23 & 46.46 & $0.33^{*}$ \\
\hline
\end{tabular}

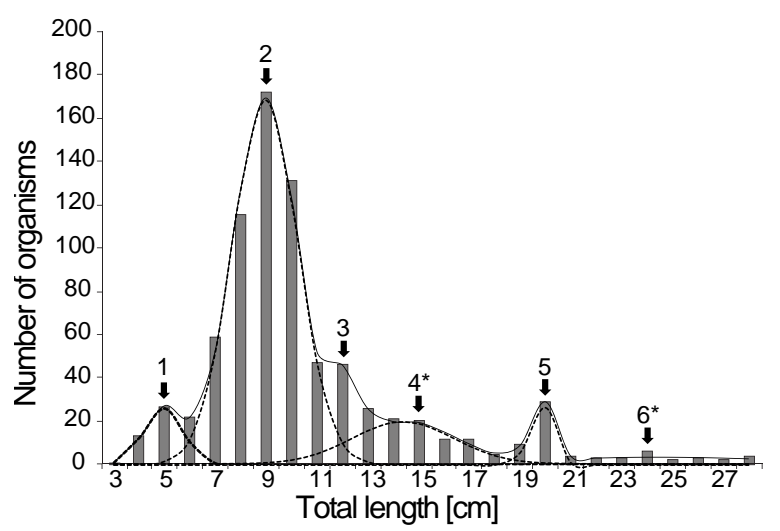

Fig. 4. Modal groups (cohorts) estimated in the lengthfrequency distribution of king angelfish, Holacanthus passer, in the Gulf of California, Mexico. *Groups with a separation index $\mathrm{SI}<2$ were not considered cohorts

The fit of the von Bertalanffy growth equation was established using the length data from cohorts 1, 2, 3, and 5, which presented separation indices greater than 2 . As mentioned in the Materials and methods, an age of 0.5 years was assigned to the first modal group, having a mean $(t+1)$ (Table 2). The growth rate of cohort $5(3.74 \mathrm{~cm}$. year $\left.{ }^{-1}\right)$ was greater than that of cohort $4\left(3.39 \mathrm{~cm} \cdot\right.$ year $\left.^{-1}\right)$, therefore the age assigned to cohort 5 was increased by one year from 4.5 to 5.5 years. Thus, the growth rate of cohort 5 was estimated to be $2.49 \mathrm{~cm} \cdot$ year $^{-1}$ (Table 2).

The adjusted von Bertalanffy growth model based on length was (Fig. 5)

$$
L_{t}=37.89\left[1-\mathrm{e}^{-0.127(t-0.658)}\right]
$$

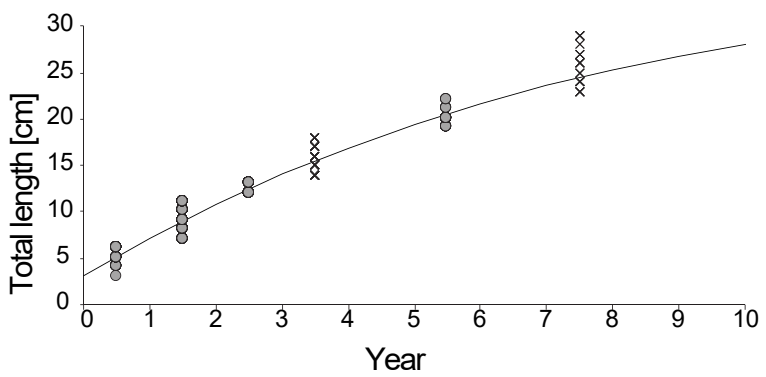

Fig. 5. von Bertanlanffy growth model (continuous black line), fit to the observed length values of each estimated cohort (gray circles) in the length-frequency distribution of king angelfish, Holacanthus passer, in the Gulf of California, Mexico; The grey crosses represent the lengths of possible modal groups $(\mathrm{SI}<2)$ that were not considered in fitting the model

The corresponding model for growth in grams as a function of age was described by the equation:

$$
W_{t}=1476.72\left[1-e^{-0.127(t-0.658)}\right]^{2.618}
$$

The first maturity length was estimated as $L_{\mathrm{m}}=21.835 \mathrm{~cm}$ (standard error 16.29-29.25), age of maturity $\left(t_{\mathrm{m}}\right)$ was 6.10 years, and longevity $t_{\max }=20.01$ years.

Mortality. According to the Hoenig (1983) method the mortality $(M)$ was 0.315 year $^{-1}$, and the total mortality $(Z)$ was 1.19 year $^{-1}(0.97-1.41,95 \%$ confidence interval). The fishing mortality $F$ amounted to 0.88 year $^{-1}(0.66-$ $1.10)$, and thus the exploitation rate $(E)$ was $0.74(0.68$ $0.78)$.

Table 2

Assigned ages per cohort in the length-frequency distribution of king angelfish, Holacanthus passer, in the Gulf of California, Mexico

\begin{tabular}{cccccc}
\hline Cohort & $\begin{array}{c}\text { Assigned age } \\
{[\text { years }]}\end{array}$ & Mean length $[\mathrm{cm}]$ & $\begin{array}{c}\text { Growth rate } \\
{[\mathrm{cm} \times \text { year }-1]}\end{array}$ & $\begin{array}{c}\text { New assigned age } \\
{[\text { years }]}\end{array}$ & $\begin{array}{c}\text { Growth rate } \\
{[\mathrm{cm} \times \text { year }-1]}\end{array}$ \\
\hline 1 & 0.50 & 4.95 & & & \\
2 & 1.50 & 8.96 & 4.01 & & \\
3 & 2.50 & 12.34 & 3.39 & 5.5 & \\
4 & 4.50 & 19.82 & $3.74^{*}$ & & \\
5 & & & & & \\
6 & & & & & \\
\hline
\end{tabular}

Note: the growth rate of the cohort was greater than that of the preceding cohort, thus a new age was assigned. 
The mortality rate for juveniles ages 0 through 6 ranged from 0.222 to 0.668 year $^{-1}$, and for adults $\left(t_{\mathrm{m}+1}-\right.$ $\left.t_{\max }\right)$ it was from 0.136 to 0.204 year $^{-1}$ (Fig. 6).

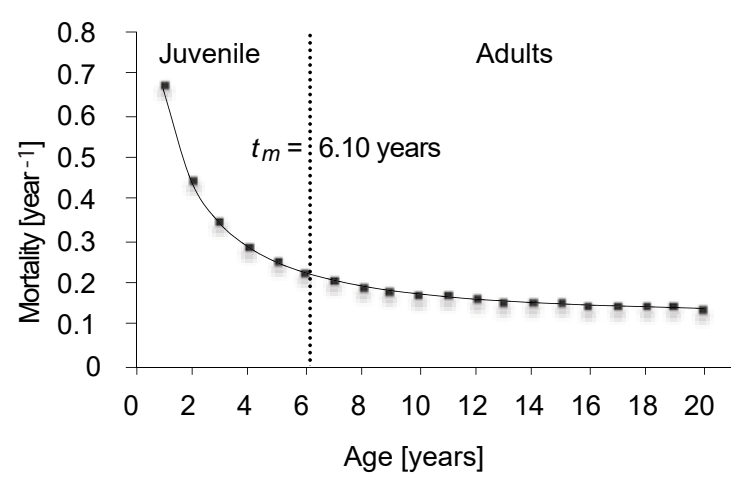

Fig. 6. Natural mortality at age of king angelfish, Holacanthus passer, in the Gulf of California, Mexico

\section{DISCUSSION}

The presently reported study is the first to address the growth and mortality rates of Holacanthus passer, although the information on other population parameters already exists. Studies on the length-weight relation in the family Pomacanthidae have been scarce. Chung and Woo (1999) and Feitosa et al. (unpublished*) reported that Pomacanthus imperator (Bloch, 1787) and Pomacanthus paru (Bloch, 1787) presented negative allometric type relation ( $b=2.77$ and 2.794, respectively). Regarding the genus Holacanthus-Marks and Klomp (2003) described $b$ values lower than 3 in Holacanthus bermudensis Goode, 1876 (2.89), Holacanthus ciliaris (Linnaeus, 1758) (2.90), and Holacanthus tricolor (Bloch, 1795) (2.85). Finally, there is only one study in reference to the Eastern Tropical Pacific, performed on angelfish-Balart et al. (2006). Those authors found an allometric relation between weight and length, but it was positive, that is, a greater relative increase in weight with respect to length $(b$ $=3.08)$. Our present estimate $(b=2.618)$ again indicates a negative allometric relation in the king angelfish, and coincides with the general pattern depicted by the family. It is possible that the results of Balart et al. (2006) are different from our results due to the small sample size examined by those authors (only 44 individuals, compared to the 794 in our sample).

The von Bertalanffy growth function represents part of the basic biological knowledge required to manage and conserve resources because they allow the definition of appropriate utilization schemes. The magnitudes of $L_{\infty}$ and $k$ permit the estimation instantaneous rates of total mortality $(Z)$ and natural mortality $(M)$, which are key to establish sustainable rates of resource use (Ochavillo and Hodson 2006), in accordance with the precautionary principle implicit in article 7.5 International Code of Conduct for Responsible Fisheries (Anonymous 1995, Sparre and Venema 1997).

Regarding the parameters of the von Bertalanffy model, Branstetter (1991) proposed a scale, based on the magnitude of the growth coefficient $(k)$, by which a species can be classified as exhibiting "slow growth" $\left(0.05 \leq k \leq 0.1\right.$ year $\left.^{-1}\right)$; "moderate growth" ( $k$ between 0.1 and 0.2 year $\left.^{-1}\right)$; or "rapid growth" $\left(k=0.2\right.$ and 0.5 year $\left.^{-1}\right)$. Considering this classification scheme, angelfish in the central region of the Gulf of California would be defined as a species of moderate growth.

The moderate growth rate of Holacanthus passer, observed in the presently reported study, might result from the fact that the individuals fed on benthic communities (algae and sessile invertebrates) and in the water column (mainly faeces from scissortail damselfish, Chromis atrilobata Gill, 1862), although they have high metabolic rates, they usually feed during the greater part of the day by browsing (Aburto-Oropeza et al. 2000, Perez-España unpublished $^{* *}$ ), like other species of rocky and coralline habitats including butterflyfishes (Chaetodontidae), surgeonfishes (Acanthuridae), and damselfishes (Pomacentridae).

The observed length frequency indicates that the majority of individuals of the king angelfish at Loreto are below the size of first maturity $(17 \mathrm{~cm})$ estimated by Arellano-Martínez et al. (1999) and in this study (from 16 to $29 \mathrm{~cm}$ ). The confirmation of the minimum size is useful as a management guideline, in order to diminish as much as possible the number of juveniles included in the catches. However, a full prohibition is not possible as the market is looking for both small and large fishes, and the current legislation in Mexico allows that.

The harvest of sexually immature specimens of Holacanthus passer, if they are exploited at high rates, could impede a large proportion of the stock from reproducing at least once, and that would lead to reductions in recruitment, and eventually bringing about deterioration of the population (Sparre and Venema 1997). For this reason our suggestion is that the management of this fishery should authorize differentiated rates of exploitation among youth and adults. In addition to ensuring the population evaluation for each capture zone.

In relation to the natural mortality, although several methods exist for its calculation (Beverton and Holt 1959, Pauly 1980, Hoenig 1983, Jensen 1997), we applied a relatively new approach proposed by Then et al. (2015). These authors conducted a review of current methods to empirically assess mortality rate in over 200 fish species, and establish that according to the performance of the equations, the best option is to use estimators based on maximum age $\left(t_{\max }\right)$. For this reason it was considered that the equation recommended by Then et al. (2015) would be the one to use in this paper, as it is congruent with the

* Feitosa C.V., Araújo M.E., Ferreira B.P. Estimates on age, growth and mortality of the French angelfish Pomacanthus paru (Bloch 1787) (Teleostei: Pomacanthidae) in the southwestern Atlantic. Journal of Applied Ichthyology [In press.]

** Pérez-España H. 2004. Hábitos alimentarios del ángel real Holacanthus passer Valenciannes, 1846 y del ángel de cortes Pomacanthus zonipectus Gill, 1863 (Osteichthyes: Pomacanthidae) en la costa sur-occidental del Golfo de California. Doctoral dissertation, Centro Interdisciplinario de Ciencias Marinas, Instituto Politécnico Nacional, La Paz, B.C.S., Mexico. 
growth pattern presented here, and with the general life cycle of the species. The calculation of mortality rates is very complex, and thus the evaluation of this parameter in the king angelfish should be improved in the future, with more detailed field studies.

There are no reports of mortality rate for Holacanthus passer in the literature, nor at genus or family level, with the exception of Pomacanthus maculosus (Forsskål, 1775) (0.12 year $\left.^{-1}\right)$ (Grandcourt et al. 2010), which as observed, it is lower than the one calculated for the king angelfish ( 0.136 to 0.204 year $\left.^{-1}\right)$. The discrepancy between maximum sizes (less than $40 \mathrm{~cm}$ in angelfish for $50 \mathrm{~cm}$ in P. maculosus, according to Froese and Pauly 2016) and the consequent higher longevity of the latter fish, may explain its lower mortality rate. In this study a specific rate of mortality for juveniles was calculated, as this population segment is an essential part of the fishery.

The most relevant use of the estimation of mortality rate of a commercial species like angelfish is its use for the establishment of catch quotas as management measures for the fishery, and also when used to evaluate total mortality (including natural and from the fishery), and exploitation rate (Fernández-Rivera Melo et al. 2008).

In presently reported study we demonstrated that exploitation rate in the area was apparently high (0.74), and this can be explained considering the fishing pressure that the species receive in the Gulf of California (ReyesBonilla et al. 2009). Under this scenario it may be useful to calculate mortality rates for specific stages of the life cycle, for a geographic region, and maybe even for a location. The reason to do so is because the gulf has a strong gradient in oceanographic conditions that also occurs in its faunas. This way, the differences in recruitment, food, refuge, temperature, and other aspects, must be affecting the natural mortality of the king angelfish, and therefore all estimations of the fishing parameters.

\section{ACKNOWLEDGEMENTS}

We are grateful to the Cooperative Society of Fish Production, "Mujeres del Golfo" for their participation in the collection of data, based on the permit No. SGPA/ DGVS/00246/09. We thank Sara Melo Merino for her support with mapping and obtaining the oceanographic data of the study site. Special thanks go to Caitlin Starks for the support in the translation of this document. FJFRM would like to recognize the support from the CONACYT for Master scholarship grant number 274238.

\section{REFERENCES}

Aburto-Oropeza O., Balart E.F. 2001. Community structure of reef fish in several habitats of rocky reef in the Gulf of California. Marine Ecology 22 (4): 283-305. DOI: $10.1046 /$ j.1439-0485.2001.01747.x

Aburto-Oropeza O., Sala E., Sánchez-Ortíz C. 2000. Feeding behavior, habitat use, and abundance of the Angelfish Holacanthus passer (Pomacanthidae) in the southern Sea of Cortés. Environmental Biology of Fishes 57 (4): 435-442.

DOI: $10.1023 / \mathrm{A}: 1007606813500$
Alvarez-Filip L., Reyes-Bonilla H., Calderon-Aguilera L. 2006. Community structure of fishes in Cabo Pulmo Reef, Gulf of California. Marine Ecology 27 (3): 253262.

DOI: $10.1111 /$ j.1439-0485.2006.00108.x

Anonymous 1995. Código de conducta para la pesca responsable. FAO, Roma, Italy.

Anonymous 2010. Protección ambiental. Especies nativas de México de flora y fauna silvestres. Categorías de riesgo y especificaciones para su inclusión, exclusión o cambio. Lista de especies en riesgo. Secretaria de Medio ambiente y Recursos Naturales, México. www.dof.gob.mx/nota_detalle. php? codigo $=5173091 \&$ fech $a=30 / 12 / 2010$.

Anonymous 2012. Plan de manejo tipo para peces marinos de ornato. Secretaria de Medio Ambiente y Recursos Naturales, México.

http://www.semarnat.gob.mx/temas/gestionambiental/ vidasilvestre/Documents/Planes\%20de\%20Manejo/ PM\%20Peces\%20Ornato\%2031\%20octubre\%202012.pdf

Arellano-Martínez M., Ceballos-Vázquez B.P., GarcíaDomínguez F., Galván-Magaña F. 1999. Reproductive biology of the king angelfish Holacanthus passer Valenciennes 1846 in the Gulf of California, Mexico. Bulletin of Marine Science 65 (3): 677-685.

Arreola-Robles J.L., Elorduy-Garay J.F. 2002. Reef fish diversity in the region of La Paz, Baja California Sur, Mexico. Bulletin of Marine Science 70 (1): 1-18.

Balart E.F., González-Cabello A., Romero-Ponce R.C., Zayas-Álvarez A., Calderón-Parra M., CamposDávila L., Findley L.T. 2006. Length-weight relationships of cryptic reef fishes from the southwestern Gulf of California, Mèxico. Journal of Applied Ichthyology 22 (4): 316-318.

DOI: $10.1111 /$ j.1439-0426.2006.00670.x

Beverton R.J.H., Holt S.J. 1959. A review of the lifespans and mortality rates of fish in nature, and their relation to growth and other physiological characteristics. Pp. 142-180. In: Wolstenholme G.E.W, O’Connor M. (eds.) CIBA Foundation colloquia on ageing: The lifespan of animals. Vol. 5. J \& A Churchill Ltd, London, UK.

Bhattacharya C.G. 1967. A simple method of resolution of a distribution into Gaussian components. Biometrics 23 (1): 115-135. DOI: $10.2307 / 2528285$

Branstetter S. 1991. Shark life history: one reason sharks are vulnerable to overfishing. Pp. 29-34. In: Gruber S.H. (ed.) Discovering sharks. Bulletin of the American Littoral Society [Special double issue] 19 (4) and 20 (1) Special publication No. 14. A Volume Honoring the Work of Stewart Springer (Underwater Naturalist). American Littoral Society, Highlands, NJ, USA.

Chen S., Watanabe S. 1989. Age dependence of natural mortality coefficient in fish population dynamics. Nippon Suisan Gakkaishi 55 (2): 205-208. DOI: $10.2331 /$ suisan.55.205

Chung K.-c., Woo N.Y.S. 1999. Age and growth by scale analysis of Pomacanthus imperator (Teleostei: 
Pomacanthidae) from Dongsha Islands, southern China. Environmental Biology of Fishes 55 (4): 399-412. DOI: 10.1023/A:1007571532648

Eschmeyer W.N., Fricke R. (eds.) 2015. Catalog of fishes: Genera, species, references. California Academy of Sciences, San Francisco, USA. http:// research.calacademy.org/research/inchthyology/ catalog/fishcatmain.asp [Accessed on 15 October 2016.]

Fernández-Rivera Melo F.J., López-Rocha J.A., Reyes-Bonilla H. 2008. Determinación de la cuota pesquera de organismos de ornato comparando tres metodologías diferentes. P. 108. In: XI Congreso Nacional de Ictiología, 28 October 2008, La Paz, Baja California Sur, México.

Froese R., Binohlan C. 2000. Empirical relationships to estimate asymptotic length, length at first maturity and length at maximum yield per recruit in fishes, with a simple method to evaluate length frequency data. Journal of Fish Biology 56 (4): 758-773. DOI: $10.1111 /$ j.1095-8649.2000.tb00870.x

Froese R., Pauly D. (eds.) 2016. FishBase. [Version 01/2016] www.fishbase.org

Gayanilo F.C., Sparre P., Pauly D. 2005. The FAOICLARM Stock Assessment Tools II (FiSAT II). Revised version. Users guide. FAO computerized information series (Fisheries). Rome, Italy.

Grandcourt E., Al Abdessalaam T.Z., Francis F., Al Shamsi A. 2010. Age-based life history parameters and status assessments of by-catch species (Lethrinus borbonicus, Lethrinus microdon, Pomacanthus maculosus and Scolopsis taeniatus) in the southern Arabian Gulf. Journal of Applied Ichthyology 26 (3): 381-389.

DOI: $10.1111 / \mathrm{j} .1439-0426.2009 .01380 . x$

Haddon M. 2001. Modelling and quantitative methods in fisheries. CRC/Chapman and Hall, Boca Raton, FL, USA.

Hilborn R., Mangel M. 1997. The ecological detective: Confronting models with data. Princeton University Press, Princeton, NJ, USA.

Hilborn R., Walters C.J. (eds.) 1992. Quantitative fisheries stock assessment and management: choice, dynamics and uncertainty. Kluwer Academic Publishers, Boston-Dordrecht-London.

DOI: 10.1007/978-1-4615-3598-0

Hoenig J.M. 1983. Empirical use of longevity data to estimate mortality rates. Fisheries Bulletin 81 (4): 898-903.

Jensen A.L. 1997. Origin of the relation between $K$ and $L_{\text {inf }}$ and synthesis of relations among life history parameters. Canadian Journal of Fisheries and Aquatic Science 54 (5): 987-989.

DOI: $10.1139 / \mathrm{f97}-007$

Locarnini R.A., Mishonov A.V., Antonov J.I., Boyer T.P., Garcia H.E., Baranova O.K., Zweng M.M., Johnson D.R. 2010. World Ocean Atlas 2009. Vol. 1: Temperature. NOAA Atlas NESDIS 68.
Marks K.W., Klomp K.D. 2003. Appendix two; Fish biomass conversion equations. In: Status of coral reefs in the western Atlantic: Results of initial surveys, Atlantic and Gulf rapid reef assessment (Agrra) Program. Atoll Research Bulletin 496 (35): 625-630.

Neter J., Kutner M.H., Wasserman W., Nachtschien J. 1996. Applied linear statistical models. McGraw-Hill/ Irwin, Chicago, IL, USA.

Ochavillo D., Hodgson G. 2006. MAQTRAC marine aquarium trade coral reef monitoring protocol data analysis and interpretation manual. Reef Check Foundation. California, USA.

Pauly D. 1980. On the interrelationships between natural mortality, growth parameters and mean environmental temperature in 175 fish stocks. Journal du Conseil Permanent international pour l'Exploration de la Mer 39 (2): 175-192.

DOI: 10.1093/icesjms/39.2.175

Pauly D. 1984. Fish population dynamics in tropical waters: a manual for use with programmable calculators. ICLARM Studies, Manila, Philippines.

Pauly D., Ingles J. 1981. Aspects of the growth and natural mortality of exploited coral reef fishes. Pp. 89-98. In: Gomez E., Birkeland C.E., Buddemeyer R.W., Johannes R.E., Marsh J.A., Tsuda R.T. (eds.) Proceedings of the Fourth International Coral Reef Symposium, Manila, Philippines. Vol. 1. Marine Science Center, Ministry of the Philippines, Quezon City, Philippines.

Pyle R., Allen G., Myers R., Zapata F., Robertson R., Rocha L.A., Craig M.T. 2010. Holacanthus passer. The IUCN Red List of Threatened Species 2010: e.T165880A6155998. http://dx.doi.org/10.2305/ IUCN.UK.2010-4.RLTS.T165880A6155998.en. [Downloaded on 15 October 2016.]

Pérez-España H., Galván-Magaña F., Abitia-Cárdenas L.A. 1996. Variaciones temporales y espaciales en la estructura de la comunidad de peces arrecífales rocosos del suroeste del Golfo de California, México. Ciencias Marinas 22 (3): 273-294.

Piña-Espallargas R., Reyes-Bonilla H., OrtuñoManzanares G., García-Núñez N.E., MendozaVargas L., González-Ania L. 2000. Recurso especies marinas de ornato. Pp. 877-914. In: Cisneros Mata M.A., Belendez Moreno L.F., Zarate Becerra E., Gaspar Dillanes M.T., González L.C., Saucedo Ruiz C., Tovar Ávila J. (eds.) Sustentabilidad y pesca responsable en México: Evolución y manejo. IPNSEMARNAP, Mexico.

Reyes-Bonilla H., Herrero-Pérezrul M.D., FernándezRivera Melo F.J. 2009. Aspectos económicos de recursos pesqueros no tradicionales, residentes en zonas arrecifales del Golfo de California. Pp. 255-264. In: Urciaga-García J., Lluch-Belda D., Beltrán-Morales L.F. (eds.) Recursos marinos y servicios ambientales en el desarrollo regional, Universidad Autónoma de Baja California Sur, Centro Interdisciplinario de Ciencias del Mar, Centro de Investigaciones Biológicas del Noroeste, Mexico. 
Ricker W.E. 1975. Computation and Interpretation of Biological Statistics of Fish Populations. Bulletin of the Fisheries Research Board of Canada, No 119. Ottawa, Canada.

Robertson D.R., Allen G.R. 2015. Shorefishes of the Tropical Eastern Pacific: online information system. Version 2.0 Smithsonian Tropical Research Institute, Balboa, Panamá.

Sánchez-Alcántara I., Aburto-Oropeza O., Balart E.F., Cupul-Magaña A., Reyes-Bonilla H., Sánchez-Ortiz C. 2006. Threatened fishes of the world: Holacanthus passer Valenciennes, 1846 (Pomacanthidae). Environmental Biology of Fishes 77 (1): 97-99.

DOI: $10.1007 / \mathrm{s} 10641-006-9047-y$

Sokal R.R., Rohlf F.J. 1987. Introduction to biostatistics. 2nd edn. Freeman, New York, NJ, USA.

Sparre P., Venema S.C. 1997. Introduction to tropical fish stock assessment. Part I. Manual. FAO Fisheries Technical Papers. FAO, Rome, Italy.

Then A.Y., Hoenig J.M., Hall N.G., Hewitt D.A. 2015. Evaluating the predictive performance of empirical estimators of natural mortality rate using information on over 200 fish species. ICES Journal of Marine Science 72 (1): 82-92.

DOI: 10.1093/icesjms/fsu136

Velázquez-Abunader I., López-Rocha J.A., ArellanoMartínez M., Ceballos-Vázquez B.P., Cabrera M.A.
2016. Estimation of growth parameters in a wild populationoflion-pawscallop(Nodipectensubnodosus) in Bahia de Los Angeles, Baja California, Mexico. Hidrobiológica 26 (1): 133-142.

Vetter E. F. 1988. Estimation of natural mortality in fish stocks: A review. Fishery Bulletin 86: 25-43.

Viesca-Lobatón C., Balart E.F., González-Cabello A., Mascareñas-OsorioI.,Reyes-BonillaH.,TorreblancaE. 2008. Los peces de arrecife de Bahía de los Ángeles, Golfo de California. Pp. 385-428. In: Danemann G., Ezcurra E. (eds). Bahía de Los Ángeles: Recursos Naturales y Comunidad. Secretaria de Medio Ambiente y Recursos Naturales- Instituto Nacional de EcologíaPronatura- Museo de Historia Natural, México.

Villáreal-Cavazos A., Reyes-Bonilla H., BermudezAlmada B., Arizpe-Covarrubias O. 2000. Los peces del arrecife de Cabo Pulmo, Golfo de California, México: Lista sistemática y aspectos de abundancia y biogeografía. Revista Biologia Tropical 48 (2-3): 413-424.

von Bertalanffy L. 1938. A quantitative theory of organic growth (inquiries on growth laws II). Human Biology 10 (2): 181-213.

Wabnitz C., Taylor M., Green E., Razak T. 2003. From ocean to aquarium. UNEP-WCMC, Cambridge, UK.

Zar J.H. 2010. Biostatistical analysis. 5th edn. Pearson Prentice-Hall, Upper Saddle River, NJ, USA.

Received: 28 October 2016

Accepted: 1 November 2016

Published electronically: 31 December 2016 